\title{
VEGETATION, SOILS, AND HYDROGEOMORPHOLOGY OF RIPARIAN PATCH TYPES OF A DRYLAND RIVER
}

\author{
K.J. Bagstad ${ }^{1}$, S.J. Lite ${ }^{2}$, and J.C. Stromberg ${ }^{2,3}$
}

\begin{abstract}
From a landscape perspective, riparian corridors can be viewed as mosaics of vegetation patches. We delineated 10 patch types within the floodplain of the San Pedro River (Arizona) on the basis of physiognomy, dominant overstory species, and tree size class; and we assessed differences in hydrogeomorphology, vegetation structure, plant species richness, and soil chemistry and texture. Patches of tamarisk (Tamarix), an introduced species, fell within the continuum of variation shown by other patch types in the landscape mosaic. Among the tree-dominated types, cottonwood-willow (Populus-Salix) and tamarisk patches were inundated more frequently than mesquite (Prosopis) patches, while cottonwood-willow patches had shallower groundwater than tamarisk or mesquite patches. Due to the wetter conditions, cottonwood-willow patches had a high relative abundance of wetland and exotic species in the understory. Tamarisk patches and wet shrublands (Baccharis salicifolia-Salix exigua) had high woody stem densities while cottonwood-willow patches had dense canopy cover. In association with differences in canopy cover, cottonwood-willow patches had low herbaceous species richness but high woody species richness, while tamarisk patches had high herbaceous and low woody species richness. Soil electrical conductivity, silt content, organic matter content, and available phosphorus increased from young to old stands of both tamarisk and cottonwood-willow, often resulting in greater differences between patches of different size/age class than between patches with different dominant species. Surface soil salinity (electrical conductivity) was low in all patches, including those dominated by tamarisk. Nitrate was abundant in soils of tamarisk patches (perhaps reflecting their high clay content) and wet shrubland patches. Dry shrublands (Hymenoclea-Ericameria) and wet shrublands were similar to young forest patches in having coarse soils with little organic matter.
\end{abstract}

Key words: Tamarix, saltcedar, Populus, Salix, Hymenoclea, Baccharis, San Pedro River, patch dynamics, exotic, succession, species richness, soils, floodplain, nutrients, salinity.

The phenomenon of patch dynamics, wherein disturbance events create a shifting mosaic of vegetation patches through time (Pickett and White 1985), plays out in river corridors of semiarid regions primarily in response to large floods (Friedman et al. 1996, Scott et al. 1997, Stromberg et al. 1997). The type of vegetation that develops after flood disturbance varies depending on landscape topography, texture of the exposed sediments, and availability of ground and surface water (Fastie 1995, Schnitzler 1995, Stringham et al. 2001). Interactions between the timing of a flood and availability of propagules also influence composition of the vegetation patch.

Flood regimes in the southwestern United States can be viewed as a mix of floods with different seasonality and climatic drivers. Highvelocity and high-duration winter floods, typically following rainstorms in El Niño years, can scour and erode extensive areas of river floodplains and terraces and deposit new sediment lenses, thereby creating opportunities for development of new vegetation patches. Along perennially flowing, low-gradient southwestern rivers, Fremont cottonwood (Populus fremontii), Goodding willow (Salix gooddingii), and seep-willow (Baccharis salicifolia) typically establish on surfaces with bare, moist mineral soils and shallow groundwater, with the relative abundance of these hydromesic pioneer species varying with timing of seedbed wetting and post-germination flood scour (Stromberg et al. 1993, Stromberg 1997, Shafroth et al. 1998, Dixon 2003). Species that are more drought tolerant or deeper rooted, including burrobrush (Hymenoclea monogyra) and mesquite (Prosopis spp.), establish on higher floodplain surfaces. Riverine marshland patches can replace forested patches on areas of widened channel beds with saturated soils or shallow water (Stromberg et al. 1997).

\footnotetext{
${ }^{1}$ MWH Americas, Inc., Chicago, IL 60604.

${ }^{2}$ School of Life Sciences, Arizona State University, Tempe, AZ 85287.

${ }^{3}$ Corresponding author.
} 
In addition to the high-magnitude floods that drive large-scale shifts in the distribution of vegetation types across the floodplain, smaller floods, which occur frequently during the summer monsoonal thunderstorm season, interact with autogenic factors to drive successional processes in the floodplain forests. Successional patterns observed in Populus floodplain forests throughout the world encompass changes in topography, chemical and physical soil traits, water availability, and vegetation structure (Wilson 1970, Bellah and Hulbert 1974, Johnson et al. 1976, Walker 1989, Boggs and Weaver 1994, Chapin et al. 1994, Stromberg 1998b, Matic et al. 1999, Sakai et al. 1999). In semiarid region floodplains, surfaces aggrade as sediment accumulates around tree bases, resulting in decreased flood inundation frequency and increased depth to groundwater. Species composition in the cottonwood-willow understory shifts over time toward species with traits adaptive in drier and more stable sites, including mesquite and big sacaton (Sporobolus wrightii).

Another post-flood successional pathway now occurs along southwestern rivers due to the recent immigration of tamarisk (Tamarix ramosissima and related species; Cooper et al. 2003). This small tree to large shrub became abundant on many southwestern rivers during the early to mid-1900s, having been introduced to the USA in the late 1800s and early 1900s for soil erosion control and landscaping purposes (Horton 1964, Robinson 1965, Graf 1982, Stromberg 1998a). Similar to cottonwood and willow, tamarisk is a disturbanceadapted pioneer species that produces many small wind- and water-dispersed seeds and requires bare, moist mineral soils for seedling establishment. Similar to mesquite, tamarisk is a deep-rooted, facultative phreatophyte that obtains water from the floodplain aquifer and from shallow soil layers and tolerates a high degree of water and salinity stress (Busch and Smith 1995, Horton et al. 2001, 2003, Vandersande et al. 2001, Horton et al. 2003). Although tamarisk can occur as an understory component in cottonwood forests, it also frequently forms its own patches, which can be extensive on some rivers.

All riparian patch types differ in some respects, but considerable research attention has been devoted to determining the ways in which tamarisk patches differ from others. With respect to species richness of various taxa, comparative studies variously have shown richness levels in tamarisk to be higher than (Ellis et al. 1997, Stromberg 1998b), equal to (Ellis 1995), or lower than (Hildebrandt and Ohmart 1982, Bailey et al. 2001) cottonwood. With respect to ecosystem processes, in-stream organic matter decomposition can be locally altered in stream reaches dominated by tamarisk (Kennedy and Hobbie 2004). Within the riparian zone, some studies report that soils under tamarisk, cottonwood-willow, and other woody species have similar salinity levels (Gary 1965, Stromberg 1998b), while some reviews suggest that tamarisk alters salinization processes (Walker and Smith 1997, Di Tomaso 1998). For all such comparisons, environmental context is important. For example, Hunter et al. (1988) reported that the degree of difference in bird species richness and composition between patches can vary across biogeographic gradients.

Differences among riparian patch types can arise due to autogenic effects caused by the dominant species in the patch or to underlying physical differences that drive the formation of one patch type versus another. Questions of how (and why) tamarisk patches differ from, or are similar to, other patch types are of interest to many river managers and conservationists, particularly in light of the large-scale, federally funded efforts that are being undertaken to control spread and dominance of tamarisk in western riparian ecosystems. More generally, understanding the processes that form vegetation patches along southwestern rivers, as well as the range of abiotic and biotic conditions associated with the patches, also can aid management efforts. For example, studies of vegetation patterns and processes at conservation sites can provide information on the range of physical conditions and processes necessary to restore particular vegetation types or diversity levels to rivers targeted for restoration activities.

The objectives of this study were to (1) delineate common riparian patch types within the floodplain-channel complex of a free-flowing desert river; (2) quantify differences between patch types in topography, hydrology, vegetation biomass structure, plant species composition and richness, and soil physical and chemical traits; and (3) determine causes of differences in traits between patches by drawing on a combination of patch-based and 
gradient analysis approaches (van Coller et al. 2000).

\section{METHODS}

\section{Study Sites}

We collected data in 2000 and 2001 at 18 study sites in Arizona along the San Pedro River from Palominas (just north of the U.S.Mexico border) to Winkelman (confluence of San Pedro and Gila Rivers; Fig. 1). This sampling area spans $218 \mathrm{~km}$ and an elevation gradient of $684 \mathrm{~m}$. Six of the 18 sites are in the San Pedro Riparian National Conservation Area (1288 to $1012 \mathrm{msl}$ ), which is within the Upper Basin of the river. Twelve are in the Lower Basin, which is recognized by hydrogeologists as beginning at the geological constriction called the Narrows (Huckleberry 1996). Upland vegetation grades from Chihuahuan desertscrub in the Upper Basin to Sonoran desertscrub in the Lower Basin.

\section{Vegetation Sampling and Data Reduction}

At each site a single transect extended perpendicular to the river on both sides, from the edge of the low-flow channel to the edge of the terrace. This zone encompassed the active channel bars and the floodplain, which includes fluvial surfaces built of sediments deposited in the present regime of the river (Graf 1988). The study area excluded the closed-canopy mesquite forests and sacaton (Sporobolus wrightii) grassland patches, that were located on terraces. Mean floodplain width, or transect length, was $295 \mathrm{~m}$. Vegetation patches were subjectively identified along transects based on differences in physiognomy (e.g., shrubland, woodland, forest, grassland, or open patch), floristics (dominant overstory or mid-story species), and seral stage (tree size class).

Within a single $1-\mathrm{m}^{2}$ plot per patch we measured herbaceous cover by species, aggregate cover (summed cover of all species), and species richness. If patches were wider than $25 \mathrm{~m}$, we added another plot for each additional $25 \mathrm{~m}$ of that patch (i.e., 2 plots for patches 26-50 m wide), for a total of 347 plots. We collected data during the early summer dry season (May-June) and late summer monsoonal wet season (August-September) in 2000 and 2001, and we averaged values across these 4 data sets. We identified plants to species using
Kearney and Peebles (1960) and appropriate revisions. A weighted average wetland indicator score was calculated for each plot by assigning numerical values ranging from 1 (obligate wetland) to 5 (obligate upland), based on wetland status for each herbaceous species as derived largely from the USDA National Plants database (USDA-NRCS 2002). Relative cover of exotic species was calculated for each plot, based on information on native vs. exotic status (to USA) reported in this same database.

We sampled woody vegetation during the growing seasons of 2000 and 2001 in 343 plots. One $5 \times 20$-m plot (oriented with the long axis perpendicular to the channel) was placed in each patch. We measured canopy cover with a spherical densiometer ( 5 points per plot) and vegetation volume using the vertical-line intercept method (1-dm intervals, 3 points per plot). We measured stem density and basal area for each woody species within the plot. Richness of woody species was calculated as number of species per $100-\mathrm{m}^{2}$ plot.

Once the field data were collected, we assigned each patch to a particular patch type using a rule-based system. First, we classified the patches according to physiognomy based on cover values within 3 strata (groundcover of $0-1 \mathrm{~m}$, mid-story of $1-5 \mathrm{~m}$, and canopy cover of $>5 \mathrm{~m}$ in height) in accordance with the National Vegetation Classification system which includes classes of forest (canopy layer $>60 \%$ ), woodland (canopy cover of $25 \%-60 \%$ ), shrubland (canopy $<25 \%$ and mid-stratum $>25 \%$ ), grassland (groundcover $>25 \%$ ), and open (groundcover <25\%; Grossman et al. 1998). The forest, woodland, and shrubland plots were further delineated based on the dominant woody species, with dominance defined as the species with the greatest basal area. We further divided the forest and woodland patches based on the stem size class (diameter) of the dominant species. This analysis produced 26 different patch types, which we collapsed into 12 major types (Table 1). We combined cottonwood-willow woodlands and forests into 1 woodland-forest type, and 3 broad age classes: young stands (maximum stem diameters $<20 \mathrm{~cm}$, which equates to age $<10$ years based on equations that relate stem diameter to tree age [Stromberg 1998a]); mature stands (stems 20 $90 \mathrm{~cm}$, age ca. $10-50$ years); and old stands (stems $>90 \mathrm{~cm}$, age $>50$ years). Tamarisk shrublands were divided into 2 broad age classes: 


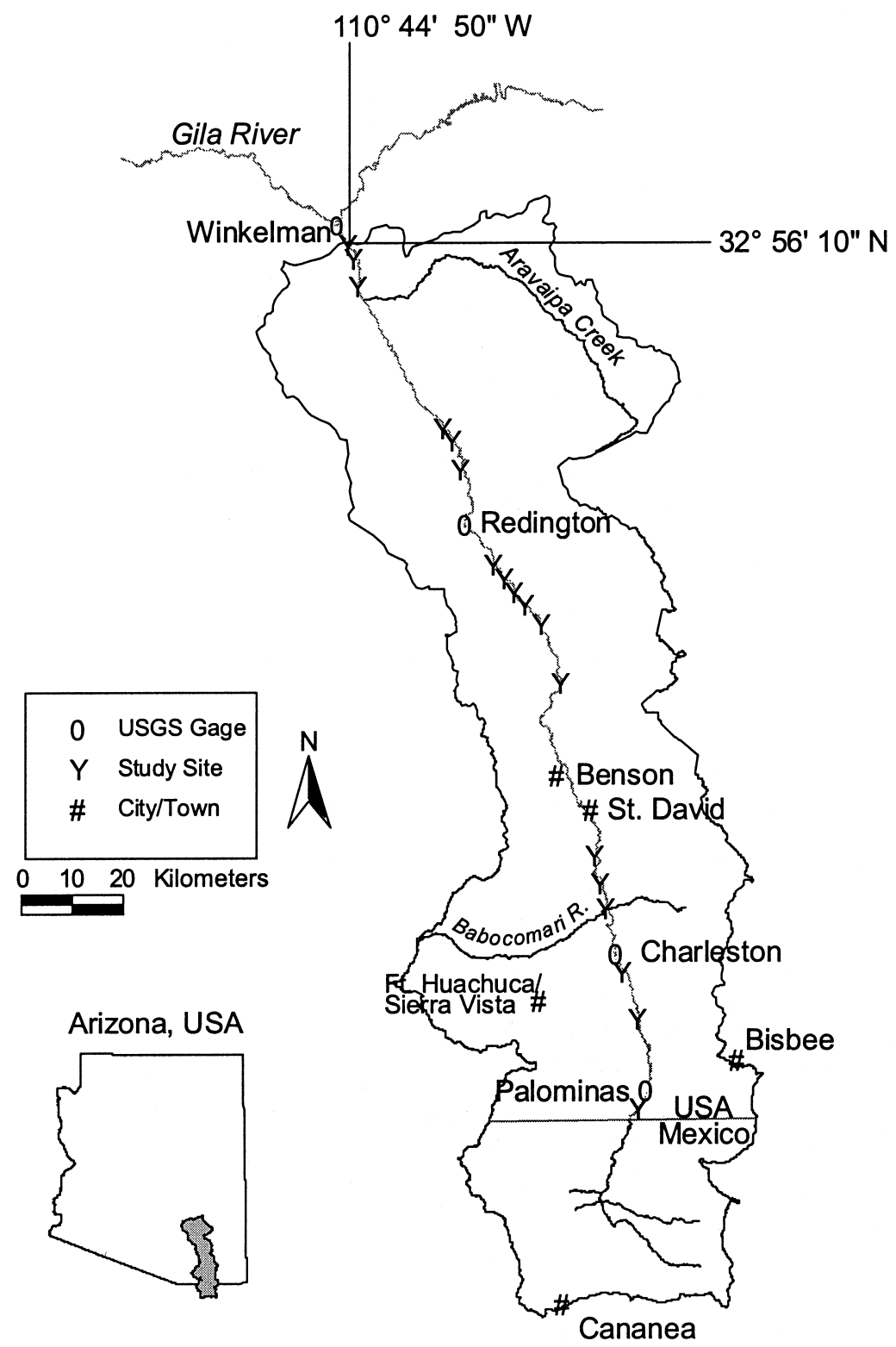

Fig. 1. Map of the San Pedro River showing locations of the 18 study sites. The San Pedro River is in the southeastern portion of Arizona, southwestern USA. Also shown are the San Pedro watershed boundary, cities and towns, and locations of 4 USGS stream gages.

young (stems $<5 \mathrm{~cm}$, age ca. $<10$ years) and mature (stems $>5 \mathrm{~cm}$, age ca. $>10$ years). Mesquite patches, which were not broken into age classes, included shrublands, woodlands, and forests; most (15 of 18) were shrublands. Mean basal diameter of the largest mesquite per patch was $16 \mathrm{~cm}$ (range from $5 \mathrm{~cm}$ to 32 $\mathrm{cm}$ among patches). Wet shrublands combine patches of narrow-leaf willow (Salix exigua), seep-willow, and emory baccharis (Baccharis emoryi); dry shrublands combine patches of burrobrush and rabbitbrush (Ericameria nauseosa). Open patches were delineated from grasslands based on mean herbaceous cover $(<25 \%$ or $>25 \%)$ as averaged across sampling times. Streamside patches were delineated 
TABLE 1. Common vegetation patch types in the floodplain and low-flow channel zones of the San Pedro River, and relative area occupied by each type.

\begin{tabular}{|c|c|c|}
\hline Patch type & Description & $\begin{array}{l}\text { Relative area } \\
\text { (\% of floodplain) }\end{array}$ \\
\hline Wet streamside & $\begin{array}{l}\text { Immediately adjacent to active stream channel, encompassing } \\
\text { channel bars and stream banks, at sites with }>70 \% \text { flow } \\
\text { permanence }\end{array}$ & - \\
\hline Dry streamside & $\begin{array}{l}\text { Immediately adjacent to active stream channel, encompassing channel } \\
\text { bars and stream banks, at sites with }<70 \% \text { flow permanence }\end{array}$ & - \\
\hline Young cottonwood-willow & $\begin{array}{l}\text { Young cottonwood or willow stand (maximum stem } \mathrm{dbh}<20 \mathrm{~cm} \text { ), } \\
\text { often bordering the active channel }\end{array}$ & $6 \%$ \\
\hline Mature cottonwood-willow & $\begin{array}{l}\text { Mature cottonwood and willow forest and woodland (max. dbh 20-90 } \\
\mathrm{cm} \text { ) on aggraded floodplain }\end{array}$ & $16 \%$ \\
\hline Old cottonwood & Old cottonwood gallery forest and woodland (>90 cm dbh) & $4 \%$ \\
\hline Young tamarisk & Young tamarisk shrubland, stems $<5 \mathrm{~cm}$ maximum $\mathrm{dbh}$ & $2 \%$ \\
\hline Mature tamarisk & Mature tamarisk shrubland, stems $>5 \mathrm{~cm}$ maximum dbh & $16 \%$ \\
\hline Wet (hydromesic) shrubland & $\begin{array}{l}\text { Shrubland dominated by Baccharis salicifolia, B. emoryi, or } \\
\text { Salix exigua }\end{array}$ & $3 \%$ \\
\hline Mesquite patches & Shrubby mesquite patches, typically without a closed canopy & $11 \%$ \\
\hline Dry (xeric) shrubland & $\begin{array}{l}\text { Open shrubland dominated by drought-tolerant shrubs including } \\
\text { Hymenoclea monogyra, often on dry, coarse soils }\end{array}$ & $7 \%$ \\
\hline Grassland & $\begin{array}{l}\text { Areas with minimal woody cover }(<25 \% \text { canopy and mid-stratum } \\
\text { cover) but }>25 \% \text { herbaceous groundcover; vegetated by annual } \\
\text { and perennial grasses (e.g., Sporobolus wrightii) and forbs }\end{array}$ & $16 \%$ \\
\hline Open patch & $\begin{array}{l}\text { Areas with minimal woody cover }(<25 \% \text { canopy and mid-stratum } \\
\text { cover) and minimal }(<25 \%) \text { herbaceous groundcover }\end{array}$ & $20 \%$ \\
\hline
\end{tabular}

based on geomorphic position and encompassed channel bars and stream banks. This type was then divided based on flow permanence: wet streamside patches were those at sites with $>70 \%$ flow permanence, and dry streamside patches were those at sites with $<70 \%$ flow permanence as measured over a 2 -year period.

\section{Abiotic Characterization}

We collected abiotic data at the patch (plot) and site scale during the same years in which we collected vegetation data. Groundwater depth was measured monthly in monitoring wells (2 at each intermittent site, 1 at each perennial site). We surveyed each transect to obtain a floodplain topographic cross section, using an autolevel transit and surveyor's stadia rod. From the cross sections, we calculated plot locations relative to the thalweg (distance from and elevation above). The groundwater surface across the floodplain was interpolated either from the 2 well points (intermittent sites) or from the river stage and single well point (perennial sites). While a linear groundwater table provides an average approximation of depth to groundwater, the assumption of linearity may not always be valid. We estimated ground-water depth for each survey point and used this information to estimate depth to the water table for each patch (plot) and to obtain a patch-width weighted-average depth to groundwater for each site, averaged for water years 2001 and 2002. We calculated inundation frequencies at each plot based on stream gage data for 4 USGS stream gages along the river (Pope et al. 1998), and we calculated stage-discharge relationships using the WinXSPRO channel cross section analyzer (West Consultants 1998; see Lite et al. 2005 for detailed methods).

We took soil samples from a subset of patch types at the study sites. We collected 3 subsamples from the streamside zone and from each of 4 spatially dominant patch types per site, and subsamples were combined. Samples were collected from the upper $15 \mathrm{~cm}$ of soil during May-June 2000 and August 2000. Values $(n=90)$ were averaged for the 2 seasons. Soil samples were analyzed for sand, silt, and clay percentages and for nitrate nitrogen, bicarbonate phosphorus, organic matter percentage, and electrical conductivity by a local analytical laboratory (Laboratory Consultants, Ltd., Lordsburg, NM). We determined gravimetric soil 
moisture by weighing sealed samples and ovendrying and reweighing the samples. Soil samples were intended to characterize the conditions for shallow-rooted herbaceous plants or newly establishing woody seedlings; they do not characterize the rhizosphere of shrubs, trees, and deep-rooted herbaceous plants.

\section{Data Analysis}

We used 1-way analysis of variance with post-hoc means separation tests (LSD) to detect significant differences between patch types in the abiotic and biotic variables. Sample size for each patch type ranged from 10 to 69 . We used analysis of covariance to determine whether particular vegetation variables (e.g., wetland indicator scores) differed significantly between pairs of patches, when controlling for the effect of abiotic factors known to be related to the variable (e.g., depth to groundwater or canopy cover as covariate; Lite et al. 2005). Here, we grouped patches into larger categories (all 3 cottonwood patch types were combined; both tamarisk patch types were combined), with sample sizes for the paired comparisons ranging from 63 to 128 . All within-test significance levels were set at $\alpha=0.05$ unless otherwise indicated. Data were analyzed using SYSTAT version 9.0 (SPSS 1998). Variables not meeting assumptions of normality, including distance and percentage-based variables, were square-root transformed prior to analysis.

\section{RESULTS}

\section{Streamside Patches}

Streamside patches were distinct in many ways from floodplain patches. Streamside soils had significantly more sand $($ mean $=79 \% \pm$ $11 \%$ ) than all other patches except wet shrublands, and less clay $(10 \% \pm 4 \%)$ than all patches except wet and dry shrublands and young tamarisk patches (Fig. 2). Organic matter in dry streamside soils was lower than in all other patch types, and values for phosphorus also were low. Streamside patches at wet sites had higher soil moisture than all other patch types including dry streamsides. Wet streamside soils had higher electrical conductivity than many other patch types including young tamarisk and young and mature cottonwoodwillow.

The herbaceous vegetation wetland indicator score for the wet streamside $(2.7 \pm 0.7)$ was significantly lower (wetter) than all other patch types (Fig. 3), reflecting the abundance of obligate to facultative wetland species including Polypogon monspeliensis, Juncus torreyi, Typha domingensis, Schoenoplectus spp., and Eleocharis montevidensis (Table 2). Relative exotic cover was high for both wet and dry streamsides, given the abundance of bermuda grass (Cynodon dactylon) in particular, with values statistically similar only to those in wet shrubland and young cottonwood-willow forest. Aggregate herbaceous cover was high for the wet streamsides $(48 \% \pm 19 \%)$, with values significantly higher than several other patch types including dry streamsides $(36 \% \pm 16 \%)$.

\section{Wet Shrublands}

Wet shrublands were located near the active channel $(47 \pm 49 \mathrm{~m})$ and had shallow groundwater $(1.7 \pm 0.7 \mathrm{~m}$; Fig. 4). Soils were sandy and had high nitrogen content, with nitrate values significantly higher than old cottonwood patches. Wet shrublands had the highest stem density of all patch types, with values significantly greater than all other types except young tamarisk (Fig. 5). Most stems were contributed by seep-willow and emory baccharis, with lower densities of narrow-leaf willow (Table 3). Wet shrublands had high relative exotic cover and a low (wet) herbaceous wetland indicator score, with values lower than several patches including dry shrubland. Common herbaceous plants included several wetland annuals (e.g., Echinochloa spp.) and the facultative upland perennial Cynodon dactylon (Table 2).

\section{Cottonwood-Willow Patches}

Elevation above thalweg increased significantly from young $(1.5 \pm 0.6 \mathrm{~m})$ to mature $(2.0$ $\pm 0.9 \mathrm{~m})$ to old patches $(2.6 \pm 1.5 \mathrm{~m})$, as did distance from the channel $(35 \pm 33 \mathrm{~m}, 108 \pm$ $88 \mathrm{~m}, 154 \pm 61 \mathrm{~m})$ and groundwater depth. Young cottonwood-willow patches had significantly shallower groundwater depth $(1.4 \pm 0.6$ $\mathrm{m})$ than all other floodplain patches except wet shrublands. Soil texture did not differ significantly among the 3 cottonwood patches, but there was a trend for soils to be finer textured in the older classes (54\% sand in young, $51 \%$ in mature, $46 \%$ in old patches). Electrical conductivity was significantly greater in old patches $\left(1.0 \pm 0.4 \mathrm{dS} \cdot \mathrm{m}^{-1}\right)$ than young patches $(0.6 \pm$ 


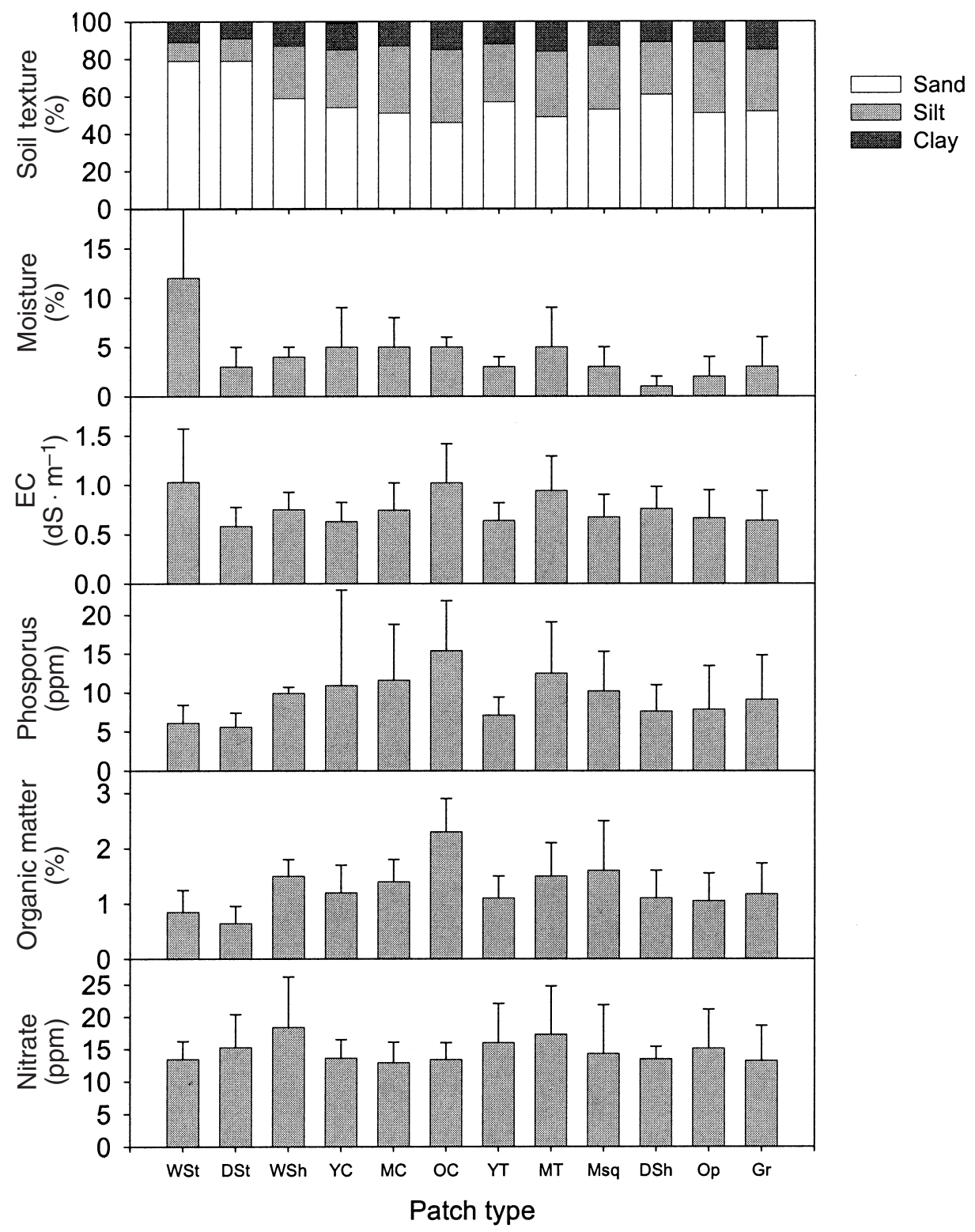

Fig. 2. Mean values (plus standard deviation) for soil traits of 12 patch types of the San Pedro River floodplain and streamside zone. Patch types are wet streamside, dry streamside, wet shrubland, young cottonwood-willow, mature cottonwoodwillow, old cottonwood, young tamarisk, mature tamarisk, mesquite, dry shrubland, open, and grassland.

$\left.0.2 \mathrm{dS} \cdot \mathrm{m}^{-1}\right)$, as was organic matter $(2.3 \%$ in old, $1.2 \%$ in young), with phosphorus marginally greater $(15 \pm 6 \mathrm{ppm}$ in old, $11 \pm 12 \mathrm{ppm}$ in young, $P=0.08)$. Electrical conductivity in old cottonwood patches was significantly greater than in many patches, including open, grassland, and mesquite. Old cottonwood soils had significantly more organic matter than all other patches and significantly more phosphorus than several patches including dry shrubland, young tamarisk and young mesquite.

Woody stem densities decreased significantly from young to mature to old cottonwood patches, while basal area increased. Old cottonwood patches had greater basal area and fewer stems than all other patches. All 3 cottonwood types 


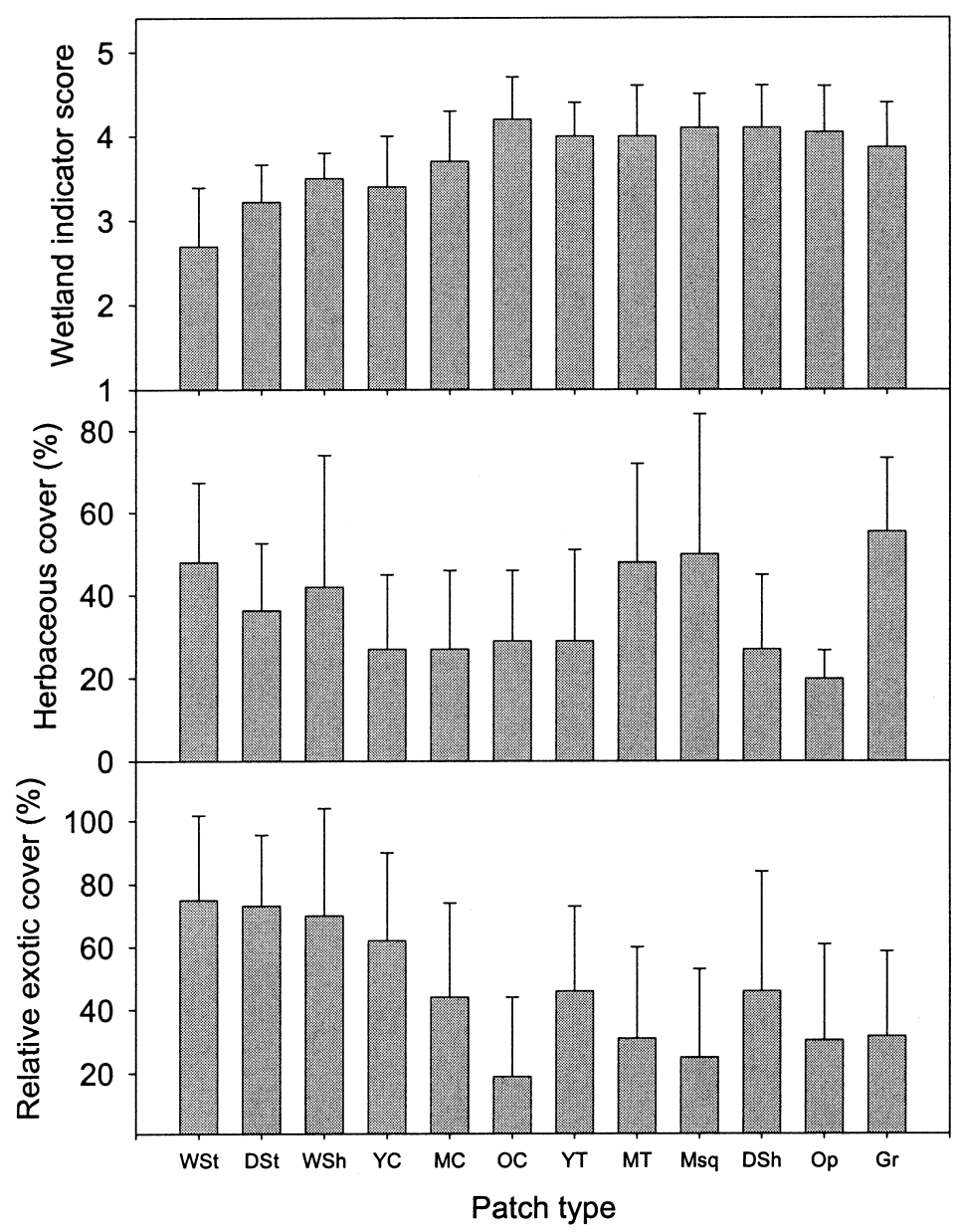

Fig. 3. Mean values (plus standard deviation) for herbaceous vegetation traits of 12 vegetation patch types (listed in Fig. 2) of the San Pedro River floodplain and streamside zone. Values are averages of 4 sampling times.

had high values for vegetation volume (means $2.7-3.0 \mathrm{~m}^{3} \cdot \mathrm{m}^{-2}$ ), with values for each significantly higher than all non-cottonwood patch types; also, they all had dense canopies $(89 \% \pm$ $17 \%$ for old cottonwood).

Old cottonwood forests had low herbaceous species richness $\left(2.0 \pm 1.0\right.$ species $\left.\cdot \mathrm{m}^{-2}\right)$, with values significantly lower than many patch types, including young tamarisk, mature tamarisk, and mesquite. In contrast, old and mature cottonwoods had high woody species richness, with values for both greater than in dry shrublands, young tamarisk, mature tamarisk, and open patches. Woody species richness values tended to increase with patch age $(4.0 \pm 1.3$, $4.6 \pm 2.0,4.6 \pm 1.6$ ), while herbaceous richness showed the opposite tendency $(2.6 \pm 1.3,2.6 \pm$ $1.2,2.0 \pm 1.0$; Fig. 6). Differences in woody species richness between cottonwood, tamarisk, and mesquite patches were partly related to canopy cover (Table 4), which was significantly positively correlated with woody species richness among all plots $(r=0.57, n=343, P<$ 0.01; Pearson product-moment correlation). Among the tree species in the understory of the old cottonwood patches were mesquite, net-leaf hackberry (Celtis reticulata), Arizona walnut (Juglans major), Goodding willow, and soapberry (Sapindus saponaria).

Young and mature cottonwood-willow patches had relatively low wetland indicator scores (3.4 \pm 0.6 and $3.7 \pm 0.6$, respectively), with values significantly wetter than in several patches including old cottonwood (4.2 \pm 0.5$)$, young tamarisk, mature tamarisk, young mesquite, dry shrubland, grasslands, and open 


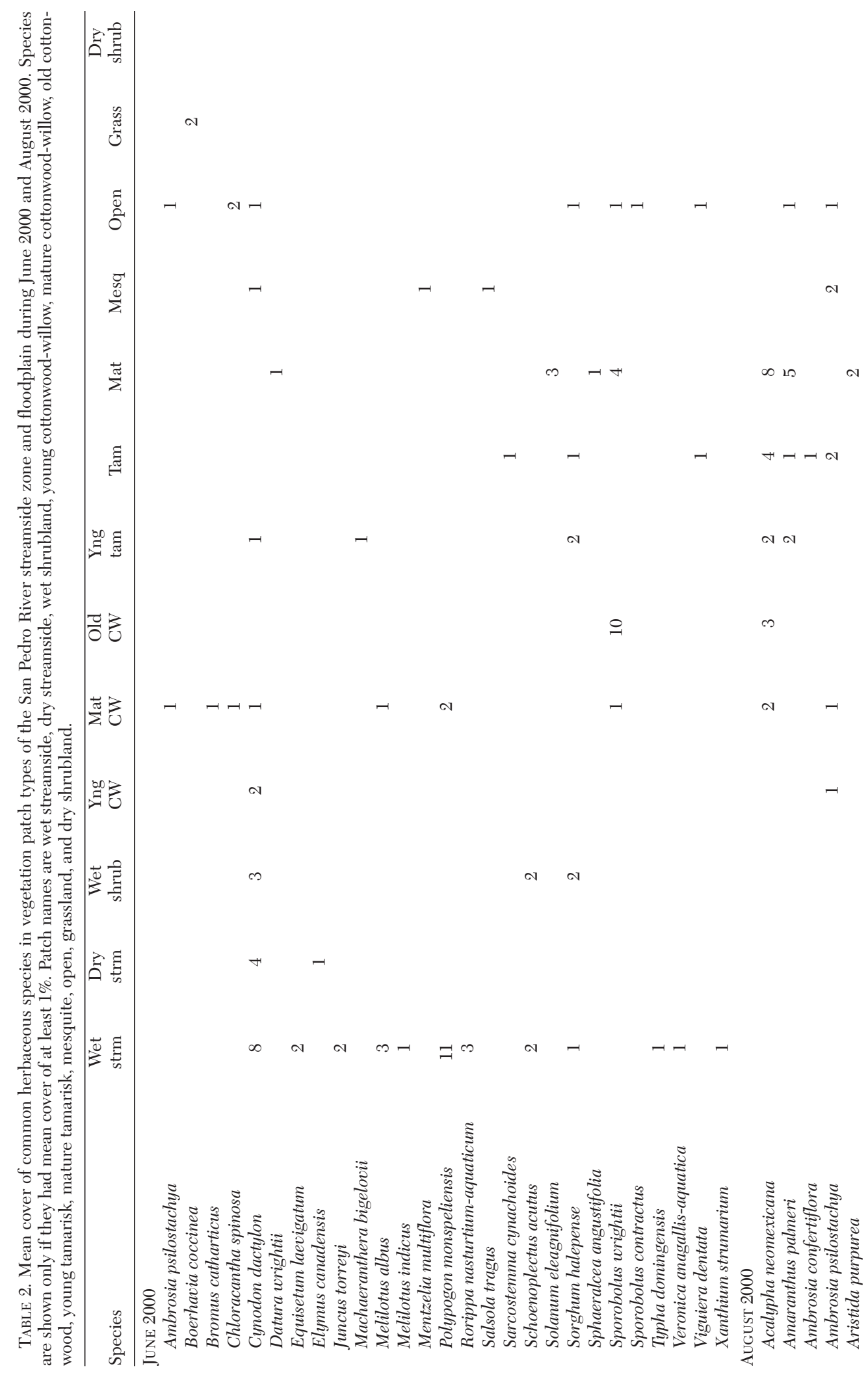




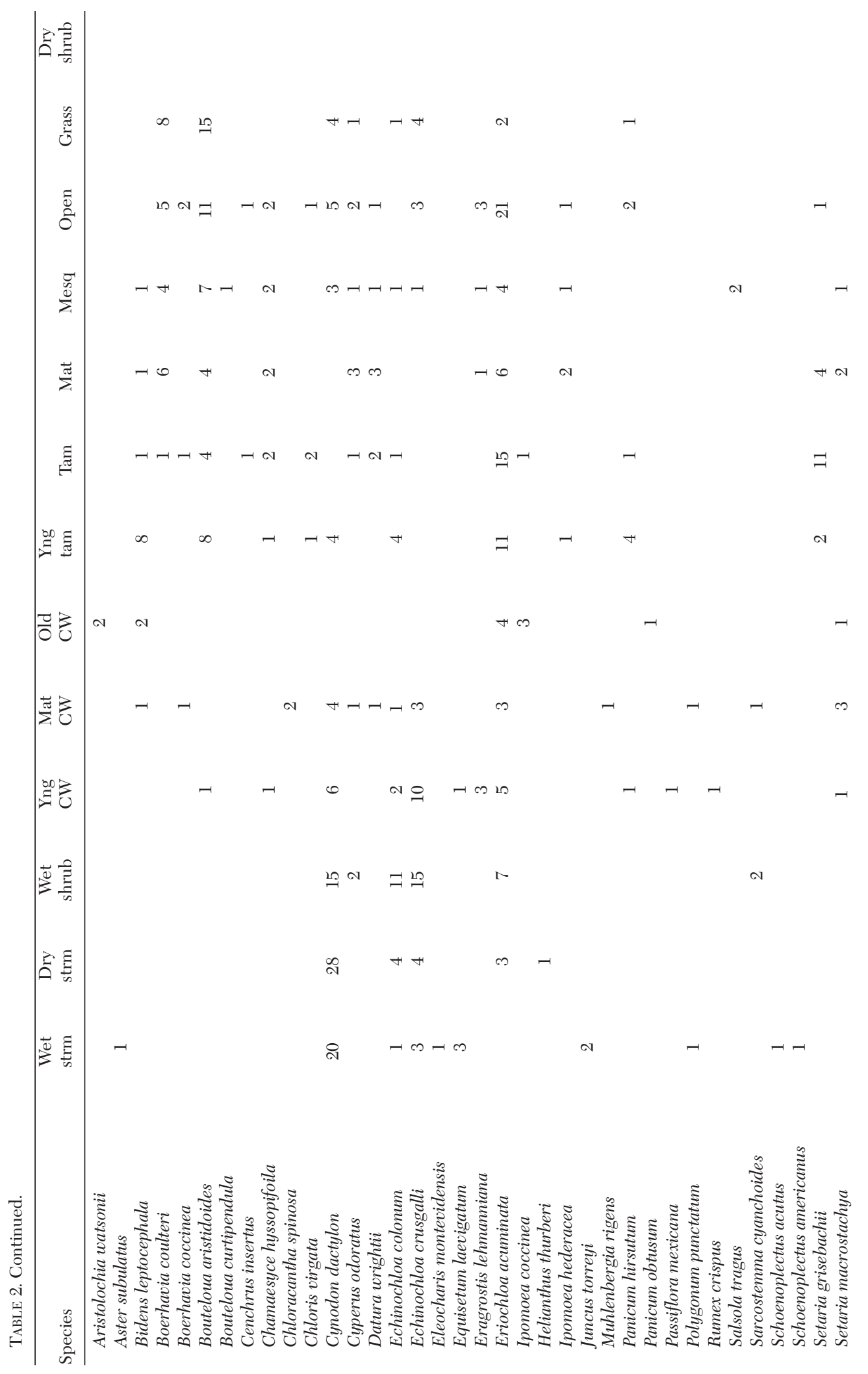




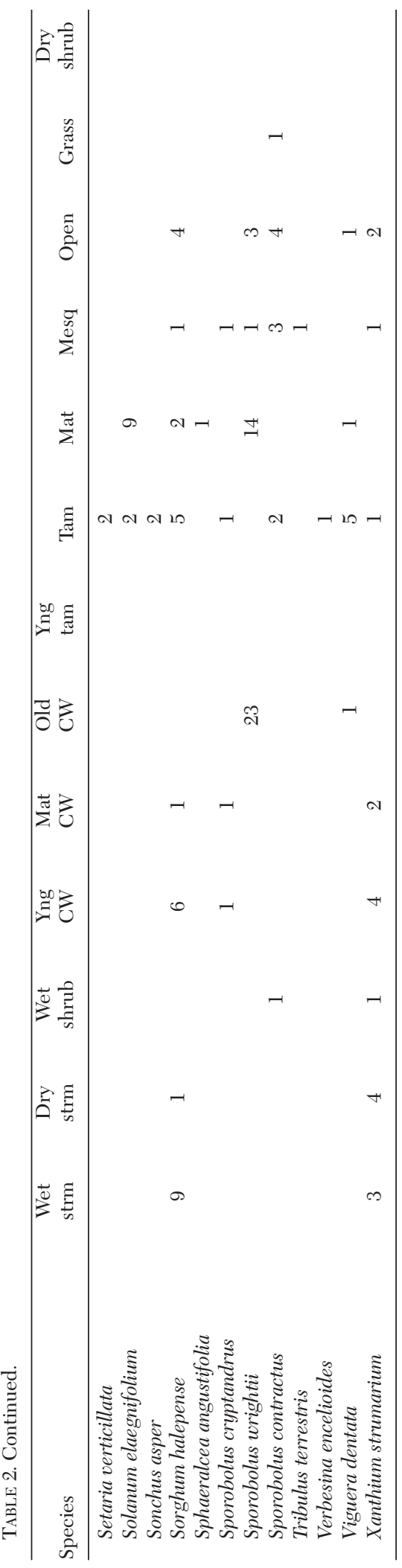

patches. Among all floodplain plots, wetland indicator scores were significantly correlated with groundwater depth $(r=-0.29, n=257$, $P<0.01)$. Results of ANCOVA indicated that groundwater depth explained some of the differences in wetland indicator scores between cottonwood and other patches (tamarisk, mesquite, open-grasslands), but that a patch effect persisted (Table 5).

The relative cover of exotic species decreased significantly from young to old cottonwood patches. Old cottonwood patches had the lowest relative herbaceous exotic cover of all patches (19\%), with values similarly low only in the mesquite patches. The relative exotic cover among all floodplain plots was significantly correlated with groundwater depth $(r=$ $0.22, n=257, P<0.01$ ), and ANCOVA indicated that cottonwood patches had significantly more relative exotic cover than other patches (tamarisk, mesquite, open-grasslands) even after controlling for groundwater depth (Table 5). Common herbaceous species in the young cottonwood patches were Echinochloa crusgalli, Erichloa acuminata, Cynodon dactylon, and Sorghum halepense. Common species in old cottonwood patches included Sporobolus wrightii, Acalypha neomexicana, Eriochloa acuminata, and Ipomoea coccinea.

Tamarisk Patches

In terms of hydrogeomorphic setting, tamarisk and cottonwood-willow patches had similar elevations above thalweg, and tamarisk and mesquite patches had similar groundwater depths. Young tamarisk patches were located $60 \pm 79 \mathrm{~m}$ from and $1.4 \pm 0.8 \mathrm{~m}$ above the channel, with values not differing significantly from young cottonwood-willow $(35 \pm 33 \mathrm{~m}, 1.5$ $\pm 0.6 \mathrm{~m})$. Mature tamarisk were located $139 \pm$ $109 \mathrm{~m}$ from the channel, with values not significantly different from mature cottonwoodwillow (108 $\pm 88 \mathrm{~m})$ and mesquite $(145 \pm 100$ $\mathrm{m})$. Mature tamarisk were $2.1 \pm 0.9 \mathrm{~m}$ above the channel, with values similar to mature cottonwood-willow $(2.0 \pm 0.9 \mathrm{~m})$ but lower than mesquite $(2.8 \pm 1.2 \mathrm{~m})$. Mean groundwater depth in mature tamarisk patches $(2.4 \pm 1.2 \mathrm{~m})$ was similar to that in mesquite but significantly greater than in young cottonwood-willow $(1.4 \pm 0.6 \mathrm{~m})$ and marginally greater $(P=$ $0.08)$ than in mature cottonwood-willow $(2.0 \pm$ $0.9 \mathrm{~m})$ patches. 


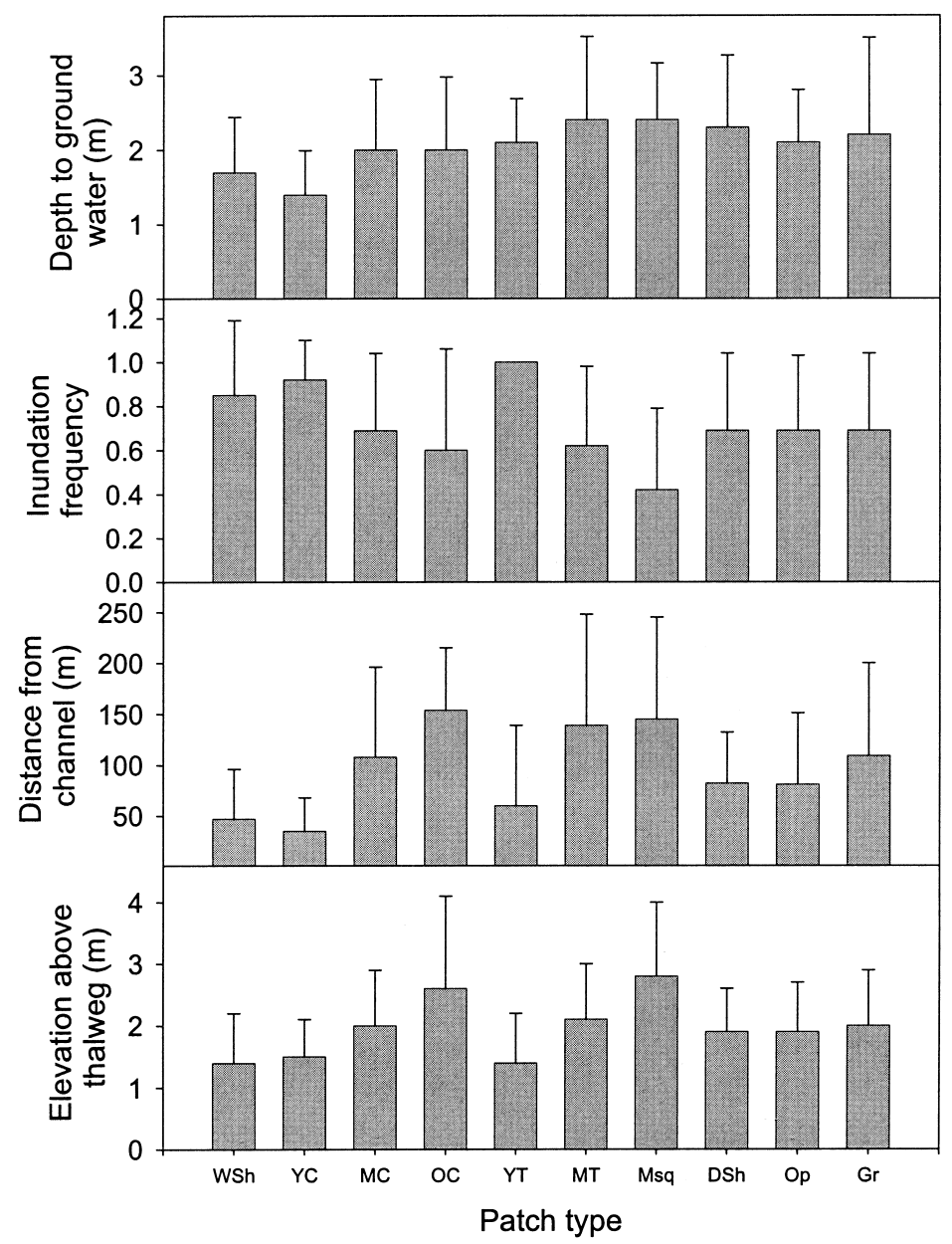

Fig. 4. Mean values (plus standard deviation) for hydrogeomorphic traits of 10 patch types (listed in Fig. 2) of the San Pedro River floodplain.

Soil moisture values in mature tamarisk, although wetter than in dry shrubland and drier then in wet streamsides, were otherwise similar to other patches. Electrical conductivity in young tamarisk was similar to that in young and mature cottonwood-willow and marginally lower than in old cottonwood $(P=$ 0.08). Electrical conductivity in mature tamarisk $\left(0.9 \pm 0.4 \mathrm{dS} \cdot \mathrm{m}^{-1}\right)$ was intermediate to that in mature cottonwood $(0.7 \pm 0.3)$ and old cottonwood $(1.0 \pm 0.4)$, with values significantly greater than for young and mature cottonwood-willow, open, grassland, and mesquite patches. Mature tamarisk patches had intermediate sand content $(49 \% \pm 26 \%)$, with values similar to many patches including mature cottonwood-willow $(50 \% \pm 20 \%)$. Mature tamarisk had high clay content $(16 \% \pm 8 \%)$, with values significantly higher than dry shrublands $(11 \%$ $\pm 3 \%)$ and wet and dry streamsides $(10 \% \pm$ $4 \%)$. Tamarisk patches had high nitrate levels, with those in mature tamarisk patches $(17 \pm 7$ ppm) significantly higher than in several patches including cottonwood patches. Many traits, including soil organic matter content, phosphorus, soil moisture, clay content, and elevation above thalweg, increased from young to mature tamarisk patches.

Structurally, tamarisk patches were similar to dry and wet shrublands in having high stem densities, reflecting the multi-stemmed growth form of the dominant species. Stem densities in young tamarisk patches were greater than in all 3 cottonwood patches, while densities in 


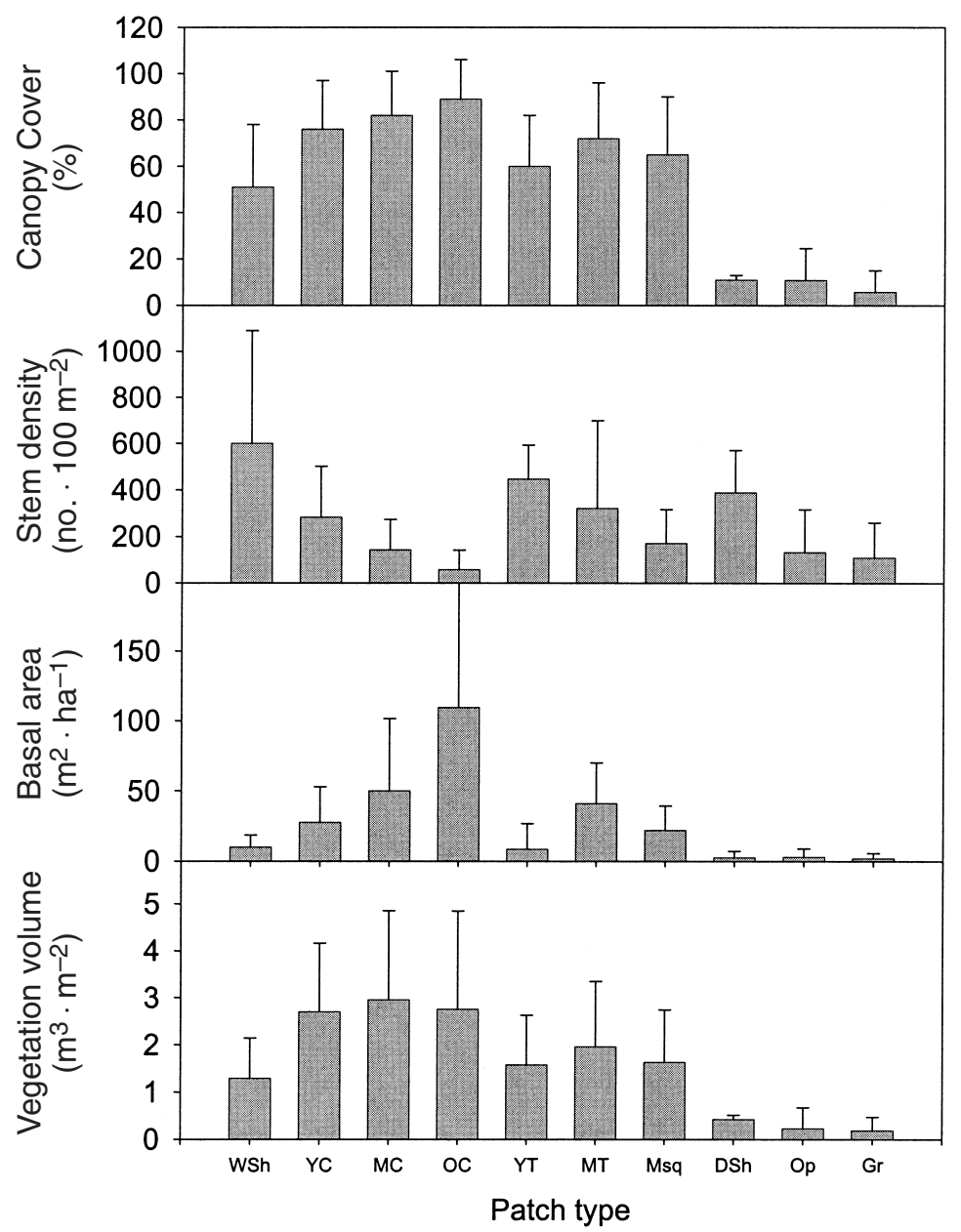

Fig. 5. Mean values (plus standard deviation) for woody vegetation structure traits of 10 patch types (listed in Fig. 2) of the San Pedro River floodplain.

mature tamarisk patches were significantly less than in wet shrublands. With respect to other biomass structure traits, tamarisk patches were most similar to either mesquite patches (vegetation volume, canopy cover) or mature cottonwood patches (woody stem basal area). Canopy cover of mature tamarisk $(72 \% \pm 24 \%)$ was marginally lower $(P=0.08)$ than old and mature cottonwood, while vegetation volume in mature tamarisk patches was significantly less than that in all 3 cottonwood patches.

Herbaceous species richness was high in tamarisk patches. Values in mature tamarisk $\left(3.3 \pm 1.4\right.$ species $\left.\cdot \mathrm{m}^{-2}\right)$ were significantly greater than in several patch types, including all cottonwood patches; values in young tamarisk ( 3.5 \pm 2.2 species $\cdot \mathrm{m}^{-2}$ ) were significantly greater than in old cottonwood patches $(2.0 \pm 1.0$ species $\left.\cdot \mathrm{m}^{-2}\right)$ and marginally greater $(P=0.07)$ than in young and mature cottonwood patches. Tamarisk patches had relatively low woody species richness. Values in young tamarisk (2.9 \pm 2.1 species $\cdot 100 \mathrm{~m}^{-2}$ ) were significantly lower than in mature and old cottonwood and young mesquite; values in mature tamarisk $\left(3.7 \pm 2.2\right.$ species $\left.\cdot 100 \mathrm{~m}^{-2}\right)$ were significantly lower than in mature cottonwood and young mesquite. Common woody species in mature tamarisk patches were seep-willow, burrobrush, and mesquite. Seep-willow and burrobrush were common in young tamarisk patches.

Wetland indicator scores for herbaceous species were high (dry) in young and mature tamarisk patches, with values statistically similar 
TABLe 3. Mean stem densities (stems per $100 \mathrm{~m}^{2}$ ) of tree and shrub species in floodplain patch types of the San Pedro River. See Table 1 for patch names.

\begin{tabular}{|c|c|c|c|c|c|c|c|c|c|}
\hline Species & $\begin{array}{c}\text { Wet } \\
\text { shrub }\end{array}$ & $\begin{array}{l}\text { Young } \\
\text { PO-SA }\end{array}$ & $\begin{array}{l}\text { Mature } \\
\text { PO-SA }\end{array}$ & $\begin{array}{c}\text { Old } \\
\text { POFR }\end{array}$ & $\begin{array}{l}\text { Young } \\
\text { TARA }\end{array}$ & $\begin{array}{c}\text { Mature } \\
\text { TARA }\end{array}$ & PRVE & $\begin{array}{l}\text { Dry } \\
\text { shrub }\end{array}$ & $\begin{array}{l}\text { Open and } \\
\text { grassland }\end{array}$ \\
\hline Acacia neovernicosa & 0 & 0 & $<0.1$ & 0 & 0 & 0 & 0 & 0 & 0 \\
\hline Baccharis salicifolia & 442.4 & 164.7 & 92.0 & 29.0 & 85.2 & 40.0 & 74.1 & 42.5 & 46 \\
\hline Celtis reticulata & 0.2 & 0 & 0.4 & 5.0 & 0.0 & 1.4 & 0.3 & 0 & 0 \\
\hline Chilopsis linearis & 0 & 0 & 0 & 0 & 0 & 0 & 0 & 0 & 0.4 \\
\hline Ericameria nauseosa & 0 & 0 & 1.8 & 3.1 & 0 & 0 & 3.9 & 32.0 & 4.1 \\
\hline Fraxinus velutina & 0.1 & 0.1 & 0.3 & 0 & 0 & 1.2 & 0.2 & 0 & 0 \\
\hline Hymenoclea monogyra & 19.8 & 41.0 & 0 & 0 & 29.2 & 6.1 & 43.1 & 300.5 & 59.2 \\
\hline Juniperus deppeana & 0 & 0 & 0 & 0 & 0.0 & 0.1 & 0 & 0 & 0 \\
\hline Juglans major & 0 & 0.1 & 0.1 & 0.2 & 0 & 0 & 0 & 0 & 0 \\
\hline Morus microphylla & 0 & 0 & $<0.01$ & 0 & 0 & 0 & 0 & 0 & 0 \\
\hline Platanus wrightii & 0 & 0 & 0 & 0 & 0 & 0 & 0 & 0 & 0 \\
\hline Populus fremontii & 7.5 & 24.3 & 8.1 & 1.5 & 0.0 & 0.8 & 0.1 & 0 & 0.5 \\
\hline Prosopis velutina & 1.8 & 0.8 & 2.9 & 7.2 & 1.7 & 2.5 & 27.8 & 1.3 & 1.8 \\
\hline Sambucus canadensis & 0 & 0 & 0.6 & 0 & 0 & 1.8 & 0 & 0 & 0.2 \\
\hline Salix exigua & 72.3 & 3.7 & 2.2 & 0 & 0 & 0 & 0 & 0 & $<0.01$ \\
\hline Salix gooddingii & 1.0 & 18.3 & 3.1 & 0.2 & 0 & 0.1 & 0.3 & 0 & 0.3 \\
\hline Sapindus saponaria & 0 & 0 & 0 & 0.2 & 0 & $<0.1$ & 0 & 0 & 0 \\
\hline Tamarix ramosissima & 53.6 & 26.2 & 28.1 & 6.9 & 327.2 & 175.3 & 16.1 & 13.5 & 11.1 \\
\hline
\end{tabular}

to those in old cottonwood, mesquite, dry shrubland, and open patches. Relative exotic herbaceous cover values in mature tamarisk patches $(31 \% \pm 29 \%)$ were less than in young and mature cottonwood $(44 \% \pm 30 \%)$ and streamsides but greater than in mesquite; values in young tamarisk patches $(46 \% \pm 27 \%)$ were less than in streamsides but greater than in old cottonwood, mesquite, grassland, mature tamarisk, and open patches. Among the herbaceous species present in the mature tamarisk understory were the grasses Setaria grisebachii and Eriochloa acuminata. Common herbaceous species in young tamarisk included Bidens leptocephala, Bouteloua aristidoides, and Panicum hirsutum.

\section{Mesquite Patches}

Mesquite patches were located on surfaces with high elevation, infrequent inundation, and deep groundwater. Elevation above thalweg averaged $2.8 \pm 1.2 \mathrm{~m}$, with values significantly greater than in all but old cottonwood patches $(2.6 \pm 1.5 \mathrm{~m})$. Mean depth to groundwater $(2.4$ $\pm 0.8 \mathrm{~m}$ ) was similar to that in mature tamarisk $(2.4 \pm 1.1 \mathrm{~m})$. Mesquite patches, like old cottonwood and mature tamarisk, were located far from the active channel $(145 \pm 100 \mathrm{~m})$. Mesquite patches had low soil moisture and intermediate values for most of the other soil traits.

Mesquite patches had high woody species richness $(4.9 \pm 1.8)$, with values greater than young tamarisk, mature tamarisk, open floodplain, and dry shrubland. Mesquite patches also had high herbaceous species richness (3.5 \pm 1.5 species $\cdot \mathrm{m}^{-2}$ ) and aggregate herbaceous cover $(50 \% \pm 34 \%)$, with values similar to those in mature tamarisk and wet shrubland but higher than in young tamarisk, dry shrubland, and all cottonwood patches. Common herbaceous species included Acalypha neomexicana, Solanum elaegnifolium, and Sporobolus wrightii; common woody species included seepwillow and burrobrush.

\section{Dry Shrublands}

Dry shrublands were located at intermediate distances from $(82 \pm 50 \mathrm{~m})$ and above $(1.9$ $\pm 1.7 \mathrm{~m})$ the channel and had intermediate groundwater depth. The main shrub species in the dry shrubland patches were burrobrush and rabbitbrush, both of which are droughttolerant and disturbance-adapted. Dry shrublands had very low soil moisture $(1 \% \pm 1 \%)$, with values significantly less than in young cottonwood, mature cottonwood, mature tamarisk, and wet streamside patches, reflecting their coarse soils and open canopies. Soils were very sandy $(61 \% \pm 25 \%)$ and had low amounts of clay $(11 \% \pm 3 \%)$, organic matter $(1.1 \%)$, and phosphorus $(7.6 \pm 3.4 \mathrm{ppm})$. Canopy cover averaged $11 \% \pm 2 \%$ and vegetation volume averaged 0.4 $\pm 0.1 \mathrm{~m}^{3} \cdot \mathrm{m}^{-2}$, with values significantly lower 


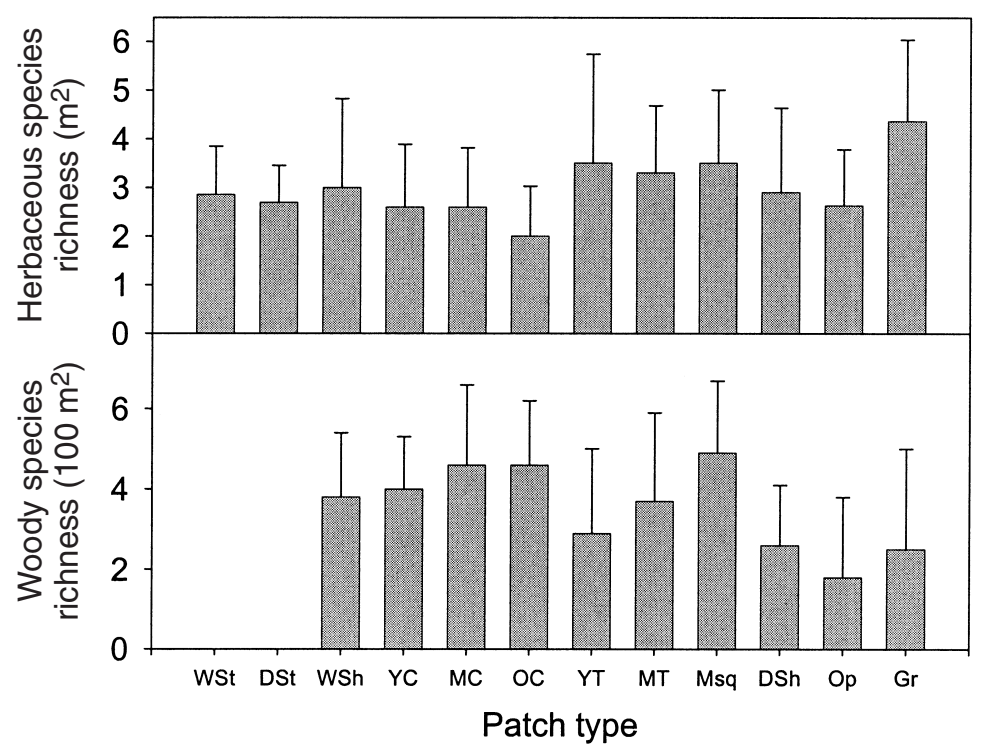

Fig. 6. Mean values (plus standard deviation) for species richness of 10 (woody) or 12 (herbaceous) patch types (listed in Fig. 2) of the San Pedro River. The herbaceous richness values are averages of 4 sampling times.

than all other patches except open patches and grasslands.

Woody species richness was low in dry shrublands, with values significantly lower than all patch types except open, grassland, wet shrubland, and young tamarisk. Herbaceous cover was low $(27 \% \pm 18 \%)$, but richness levels were intermediate $\left(2.9 \pm 1.7\right.$ species $\left.\cdot \mathrm{m}^{-2}\right)$. Herbaceous vegetation had a high (dry) wetland indicator score, with common species including the annuals Bouteloua aristidoides and Boerhavia coulterii.

\section{Grasslands and Open Floodplain Patches}

Similar to dry shrublands, grasslands and open floodplain patches occurred at intermediate distances from and above the channel and had intermediate groundwater depths. Many soil traits had intermediate values. Woody species richness was low, but herbaceous species richness in the grasslands was high, with values significantly greater than all other patch types. Herbaceous cover in the grasslands was abundant, with values similarly high only in mesquite and wet streamside patches. Annual grasses (e.g., Bouteloua aristidoides, Eriochloa acuminata) and perennial grasses (e.g., Sporobolus contractus, S. wrightii) were the dominant herbaceous species, with forbs also present.

\section{Discussion}

Along the San Pedro River, as on many rivers worldwide, several patch types that differ in physiognomy, dominant overstory species, and tree age coexist in the channel-floodplain complex (Harris 1987, Hupp and Osterkamp 1996, Higgins et al. 1997, Hughes 1997). This landscape diversity is a product of an active flood regime that, over time, removes vegetation from portions of the floodplain, redistributes sediments, and forms new fluvial surfaces that can differ in abiotic conditions. Each of the dominant woody species in the riparian corridor has different abiotic requirements and environmental tolerance ranges for seedling establishment, and thus variation in initial establishment conditions produces different environments among patch types. Post-establishment successional changes lead to additional environmental differences among patches.

\section{Differences Among Tree-dominated Patches}

Hydrogeomorphology.-The environmental differences observed among cottonwoodwillow, tamarisk, and mesquite patches partly reflect differences in initial physical conditions at the time of tree establishment. In terms of hydrogeomorphic setting, the low 
TABLE 4. Results of analysis of covariance comparing woody species richness between pairs of patch types. Canopy cover is a covariate in the models. Values shown are significance levels ( $P$-values).

\begin{tabular}{lcc}
\hline Comparison & $\begin{array}{c}\text { Patch } \\
\text { effect }\end{array}$ & $\begin{array}{c}\text { Canopy } \\
\text { effect }\end{array}$ \\
\hline Mesquite vs. open & 0.98 & 0.00 \\
Cottonwood vs. open & 0.15 & 0.00 \\
Tamarisk vs. open & 0.08 & 0.00 \\
Cottonwood vs. tamarisk & 0.04 & 0.08 \\
Cottonwood vs. mesquite & 0.06 & 0.01 \\
Tamarisk vs. mesquite & 0.01 & 0.28 \\
\hline
\end{tabular}

elevation and proximity to the channel of the young tamarisk and young cottonwood-willow patches reflect the fact that tamarisk, cottonwood, and willow are pioneer species that establish on flood-disturbed surfaces; the deeper groundwater under tamarisk patches reflects tamarisk's greater rooting depth and lower competitive ability compared with cottonwoods (Sher et al. 2000, 2002, Lite and Stromberg 2005). Mesquite patches had deep groundwater, similar to tamarisk, but were located on surfaces with high elevation and infrequent inundation; this pattern reflects mesquite's low tolerance of saturated soils, high drought tolerance, and large seed size that enables rapid root growth to deep water tables (Stromberg 1993).

HerbaCEOUS UNDERSTORY COMPOSITION.Some patch differences in composition of the herbaceous understory layer were attributable to physical setting. With respect to herbaceous species composition, 2 trends were apparent across patch types: relative exotic cover and relative cover of wetland species were both greater in patches (i.e., streamsides, young cottonwood-willow, wet shrublands) located on fluvial surfaces underlain by shallow groundwater. Cottonwood-willow patches thus had greater understory abundance of wetland and exotic species than did tamarisk and mesquite patches partly due to differences in hydrogeomorphic setting. The pattern for herbaceous exotics contrasts with that observed by Holl and Crone (2004) in a California riparian corridor, wherein cover and species richness of exotic understory species was lowest on surfaces closest to the river base flow. On the San Pedro the abundance of exotics near the river may reflect the long agricultural history and preponderance of agricultural weeds in the riparian flora, many of which have relatively high water needs.
Autogenic effects also influenced understory composition, as suggested by the persistence of patch differences in both measures of plant species composition (wetland and exotic cover) after controlling for groundwater. Cottonwoods, willows, tamarisk, and mesquite likely modify their environments in different ways. The dense shade of the cottonwoods may produce cooler temperature and higher humidity, favoring a different suite of understory species. The trees also vary among species and sites in the amount of water they uptake from shallow versus deep soil layers (Snyder and Williams 2000, Horton et al. 2003), resulting in various degrees of depletion of the shallow soil water used by many herbaceous plants. Phreatophytic tree species also differ in rates of hydraulic lift or hydraulic redistribution (Hultine et al. 2003), with one study suggesting greater redistribution of water to shallow soil layers by tamarisk (McQueen and Miller 1972). We did not find substantial differences in surface soil water content between most floodplain patches (with dry shrublands being the only distinctively dry patch, likely due to the combination of very coarse soils, low organic matter, and high solar radiation), but our investigation did not address water throughout the soil column, nor was sampling sufficiently frequent to detect robust temporal trends.

HerbaCEOUS SPECIES RICHNESS.-Herbaceous species richness values were relatively similar among many patches, reflecting the interactive effects of many influences on richness. Gradient studies on the San Pedro River have shown that richness of herbaceous species is positively correlated with shallow groundwater and proximity to the channel in dry seasons, and richness increases on higher surfaces in wet seasons, perhaps due to lower frequency of scour on such surfaces (Lite et al. 2005). Groundwater depth and inundation frequency vary in opposing ways across the floodplain continuum, thus minimizing richness differences among patches. However, a very small positive effect of increased elevation above thalweg persisted $(r=0.18, n=347, P<0.01$; Lite et al. 2005). Thus, topographic position may partly explain the higher values for seasonally averaged herbaceous richness recorded in mesquite patches.

Canopy cover, which varied widely among patch types, was correlated with herbaceous richness patterns, with richness being greatest 
TABLE 5. Results of analysis of covariance comparing herbaceous wetland indicator scores and relative exotic herbaceous cover between pairs of patch types. Groundwater depth $(\mathrm{GW})$ is a covariate in the models. Values shown are significance levels ( $P$-values).

\begin{tabular}{|c|c|c|c|c|}
\hline \multirow[b]{2}{*}{ Comparison } & \multicolumn{2}{|c|}{ Wetland indicator score } & \multicolumn{2}{|c|}{ Relative exotic cover } \\
\hline & Patch effect & GW effect & Patch effect & GW effect \\
\hline Cottonwood vs. tamarisk & 0.03 & 0.03 & 0.05 & 0.03 \\
\hline Cottonwood vs. mesquite & 0.01 & 0.00 & 0.01 & 0.00 \\
\hline Cottonwood vs. open & 0.01 & 0.01 & 0.01 & 0.01 \\
\hline Tamarisk vs. mesquite & 0.37 & 0.01 & 0.32 & 0.28 \\
\hline Tamarisk vs. open & 0.57 & 0.01 & 0.65 & 0.23 \\
\hline Mesquite vs. open & 0.14 & 0.02 & 0.25 & 0.06 \\
\hline
\end{tabular}

in the most open patches (grasslands) and lowest in those with densest canopy (old cottonwood stands). Gradient studies along the San Pedro show herbaceous species richness to be positively and negatively correlated with canopy cover, depending on season (positively in dry, negatively in wet; Lite et al. 2005), with a very small net negative effect persisting across seasons $(r=-0.14, n=347, P<0.01)$. Dense canopy is associated with reduced understory species richness in many riparian ecosystems (Pabst and Spies 1998, Zimmerman et al. 1999). Herbaceous species richness in the densely canopied cottonwood patches may be low due to light limitation effects or to suppression of germination and seedling establishment by the thick litter cover that develops under the dense canopies. Sparser canopies of tamarisk and mesquite patches may increase richness of herbaceous understory species by allowing greater light penetration to the understory, or the small leaves of tamarisk and mesquite may create a litter layer that more readily allows for germination of small-seeded species (Xiong et al. 2001).

WOODY SPECIES RICHNESS.-Herbaceous and woody species richness patterns varied independently among patches on the San Pedro River, consistent with other studies showing independent variance of vegetation strata across environmental gradients and over time (Sagers and Lyon 1997, Lyon and Sagers 1998, Lite et al. 2005). Cottonwood patches had low herbaceous species richness but high woody species richness, while the reverse pattern (high herbaceous richness, low woody richness) was true for tamarisk and open patches; only mesquite patches had high values for both herbaceous and woody species richness. In contrast to patterns for herbaceous richness, gradient studies on the San Pedro River show canopy cover to be strongly positively related to woody species richness (Lite et al. 2005). Several woody species in the cottonwood understory (e.g., Juglans major) are broadleaf trees that have large, animal-dispersed seeds and that find the lower end of their elevational range along the lower San Pedro River. Dense cottonwood canopies may mediate the thermal environment and create conditions that allow seedling survivorship of these successional species while also creating suitable microsites for the animals that disperse their seeds.

When considering woody species, results for the San Pedro are similar to other studies that report low plant species richness in tamarisk patches. Ellis (1995), for example, reported fewer woody species (3 species) in tamarisk patches than in cottonwood patches (9 species) along the Rio Grande, although sample size was very small (2 tamarisk patches and 2 cottonwood patches). Hildebrandt and Ohmart (1982) found fewer plant woody species in tamarisk (0.3 species) than in cottonwood-willow (0.9 species) or honey mesquite (Prosopis glandulosa; 2.9 species) along the Pecos River. When considering herbaceous species richness, results for the San Pedro are consistent with a previous study on this same river (Stromberg 1998b) but are inconsistent with the few studies that have addressed this floristic component, including Hildebrandt and Ohmart (1982), who found 4.9 herbaceous species in tamarisk, 12.4 in cottonwood-willow, and 10.1 in honey mesquite. The differences may arise due to environmental context of the study rivers. The 2 studies cited above, as well as a study by Engel-Wilson and Ohmart (1978) that alludes to lower richness in tamarisk than cottonwoodwillow stands, were all conducted on dammed, flow-regulated rivers, where species effects are confounded by site effects caused by changes 
in the physical processes that regulate species diversity. These other studies also did not take into account differences that may arise due to stand age or hydrogeomorphic setting of the patches.

SOIL TEXTURE.-Overall, there was much within-patch variation in soil texture. Spatial patterns of sediment deposition can be complex in floodplains due to within-patch variance in vegetation density, floodplain topography, proximity to tributaries, and between-flood differences in sediment loads (Brock 1985). Although clay content did not differ significantly among woody patch types, there was a trend for values to be high in mature tamarisk, similar to findings of Gary (1965) and Stromberg (1998b). Clay may be abundant in some tamarisk soils due to high stem density or to extruded salt on plant stems and leaves that flocculate the clay and induce settling (Everitt 1980). Wet shrublands also had high stem density but only intermediate clay content. These wet shrublands occurred on young fluvial surfaces that have a different depositional history than do mature tamarisk patches on distal floodplains.

SOIL NUTRIENTS.-Nitrate levels were somewhat elevated in tamarisk and wet shrubland patches. Nitrate levels were significantly correlated with clay content across individual patches (Pearson's $r=0.38, n=90, P<0.05$ ), and it may be that the high clay content present in some tamarisk soils reduces rates of nitrate leaching (Dimitriou and Aronsson 2004). Some forms of soil nitrogen can be high if there is an abundance of legumes that harbor nitrogen-fixing Rhizobium spp. or of plants such as Alnus that harbor the actinomycete Frankia spp. (Johnson et al. 1976, Virginia and Jarrel 1983, Walker 1989), but no such plants, to our knowledge, were common in the tamarisk or wet shrubland patches. Nitrate levels in mesquite patches were intermediate despite the likely presence of nitrogen-fixing symbionts in the mesquite roots. Frequent flooding in the floodplain mesquite patches may prevent nitrogen compounds from accumulating to the high levels observed on riparian terraces (Stromberg unpublished data, Schede et al. 2005) or other low-disturbance settings (Virginia and Jarrell 1983).

SOIL SALINITY.-Several reviews of tamarisk ecology have reported that salt levels can accumulate in surface soils under tamarisk stands. Di Tamaso (1998:334) stated that "salts are redistributed over time from deep within the soil profile to become concentrated on the soil surface of floodplains (Shafroth et al. 1995)," although the reference he cited was an experiment on effects of salinity on germination rates rather than a study of salt movement or soil salinization. Shafroth et al. (1995) only speculated that the high salinities observed in some floodplain sediments (e.g., $10 \mathrm{dS} \cdot \mathrm{m}^{-1}$ or ca. $10 \mathrm{mmhos} \cdot \mathrm{cm}^{-1}$ on regulated reaches of the Rio Grande and Colorado) are caused by evaporation of soil water and salt extrusion from tamarisk leaves. In another review, Walker and Smith (1997:84) state that "salinization of floodplain habitats may be the most important single way that the invasion of salt-cedar fundamentally alters ecosystems." Along the San Pedro, salinities were low overall, with trends for highest values on wet streamsides and older stands of both cottonwood and tamarisk. Gary (1965) found no significant differences in conductivity between mesquite, arroweed (Pluchea sericea), and tamarisk soils along the Salt River (central Arizona). Electrical conductivities in the surface soils of San Pedro tamarisk stands soils (ca. $1 \mathrm{dS} \cdot \mathrm{m}^{-1}$ ) are much lower than those reported on some rivers, such as the 45 $\mathrm{dS} \cdot \mathrm{m}^{-1}$ measured on the flow-regulated Gila River (Van Hylckama 1980). The chloride content on tamarisk leaves varies depending on the abundance of chloride in groundwater (Hem 1967). Frequent flushing of soils by floods, combined with lack of saline water sources to concentrate, may explain the overall low levels of salinity for all of the San Pedro River riparian patch types. While tamarisk certainly may contibute to surface salinization in some environmental contexts, it is also possible that the association of tamarisk species with salinity, reported by Salinas et al. (2000), Busch and Smith (1995), and others, arises because the plants are physiologically able to persist on sites that are naturally saline or that have increased in salinity due to human alterations including inflows of agricultural runoff, suppression of river flooding, and retention of water in reservoirs (Anderson 1996).

\section{Patches of Different Size / Age Class}

TOPOGRAPHY AND UNDERSTORY VEGETATION.-Among the various size classes of cottonwood-willow and tamarisk, environmental 
differences were apparent that reflected successional processes. The floodplain surfaces of older patches had greater elevation above thalweg and greater depth to groundwater, reflecting some combination of floodplain aggradation and channel incision processes, a common trend observed in floodplain forests. Most deposition (as well as erosion) in aridregion rivers occurs episodically during large, infrequent floods, but the cumulative effects of aggradation from small floods can be great as well (Minckley and Clark 1984). Fine particles (silts and clays) entrained in floodwaters settle out as floodwater velocities decrease, with the high stem density and basal area in the forest stands inducing deposition of suspended loads by increasing Manning's roughness coefficient. Sediments are then stabilized in the understory by plant root growth. As floodplains aggrade, flood inundation frequency declines while groundwater depth increases. These successional changes produced differences in topography between age classes of cottonwood-willow and of tamarisk that were greater than differences between species within an age class (e.g., 33\% difference in elevation above thalweg between young and mature cottonwood-willow, 7\% difference between young cottonwood-willow and young tamarisk). Lower values for exotic species in the herbaceous understory of older forest patches likely reflect aggradation processes that have reduced inundation frequency, increased depth to groundwater, and created drier conditions for herbaceous plant growth. Lower rates of flood disturbance also may contribute to the reduced abundance of exotics, many of which are disturbance-adapted ruderals. Decline in exotics with stand age is common in many types of forested ecosystems (Brockerhoff et al. 2003, Selmants and Knight 2003).

SoILS.-Newly deposited San Pedro River sediments on which Fremont cottonwood, Goodding willow, and tamarisk established were coarse (high sand) and low in organic matter. Sediments in older patches were finer grained, similar to patterns observed on many other rivers (Wilson 1970, Fonda 1974, Johnson et al. 1976, Walker 1989, Nakamura et al. 1997, Adair et al. 2004). As was the case for topography, these successional changes produced differences among age classes within a species that were comparable to differences among patches supporting different species.
For example, clay content differed by an average of $15 \%$ between mature and old cottonwoodwillow patches and by $23 \%$ between mature cottonwood and mature tamarisk patches.

Organic matter and nutrients typically accumulate in older floodplain soils due to autogenic soil-building processes in concert with reduced frequency of scour of leaf litter and other plant debris (Johnson et al. 1976, Bush and Van Auken 1986, Chapin et al. 1994, Schwendenmann 2000, Adair et al. 2004). Although available phosphorus and organic matter in this study were greater for older than younger stands of both tamarisk and cottonwood-willow, soil nitrate levels did not vary between patches of different size (contrasting with findings of Stromberg 1998b), perhaps due to high spatial variability in the many factors that influence nitrogen availability in riparian zones, including inputs from floodborne sediments and nitrogen-fixing plant species, and outputs from leaching, plant uptake, and microbial transformations. Some studies report that soil water (or available water capacity) increases through time in riparian forests due to increased retention of organic matter in soils (Wilson 1970, Johnson et al. 1976, Chapin et al. 1994, Nakamura et al. 1997), but we did not find corresponding differences in soil moisture between age classes.

Soil traits of the wet shrublands and dry shrublands were similar in many ways to those of the young age classes of tamarisk and cottonwood-willow, with all having coarse soil texture and low levels of organic matter and phosphorus. This suggests that there has been little post-establishment soil change for both wet and dry shrublands. However, age of the shrubs on these patches is not known, and thus rate and extent of successional changes remain to be determined.

\section{Management Applications}

Conservationists and ecosystem managers frequently strive to prevent changes that fall beyond some range of natural variability (Landres et al. 1999). Tamarisk patches along the San Pedro River fall within the continuum of variation shown by other patch types in the landscape mosaic with respect to soil, vegetation, and hydrogeomorphic traits we measured. All riparian patch types had a distinct environmental signature, and differences between tamarisk patches and other patch types were 
not remarkable. For many traits of wooded patch types, differences among patches that differed in age class were as great as, or greater than differences among patches that differed in dominant species. Based on the parameters we measured in this study, there seems to be no compelling reason to assign any special management status to the tamarisk patches on the San Pedro River. From a conservation perspective, it does seem important to maintain the processes (e.g., active flood regime, shallow groundwater flows) that maintain a complex riparian landscape composed of patches ranging from wet to dry shrublands, young to old forests, and open areas to densely vegetated grasslands.

\section{ACKNOWLEDMENTS}

Funding for this study was provided in part by the NSF Science and Technology Center for the Sustainability of semi-Arid Hydrology and Riparian Areas.

\section{Literature Cited}

Adair, E.C., D. Binkley, And D.C. Andersen. 2004. Patterns of nitrogen accumulation and cycling in riparian floodplain ecosystems along the Green and Yampa Rivers. Oecologia 139:108-116.

Anderson, B.W. 1996, Salt cedar, revegetation and riparian ecosystems in the Southwest. Pages 1-13 in J. Lovitch, J. Randall, and M. Kelly, editors, Proceedings of the California Exotic Pest Plant Council Symposium. California Exotic Pest Plant Council, Davis.

Bailey, J.K, J.A. Schweitzer, and T.G. Whitham. 2001. Salt cedar negatively affects biodiversity of aquatic macroinvertebrates. Wetlands 21:442-447.

Bellah, R.G., AND L.C. Hulbert. 1974. Forest succession on the Republican River floodplain in Clay County, Kansas. Southwestern Naturalist 19:155-163.

Boggs, K., And T. Weaver. 1994. Changes in vegetation and nutrient pools during riparian succession. Wetlands 14:98-109.

BRock, J.H. 1985. Physical characteristics and pedogenesis of soils in riparian habitats along the upper Gila River basin. U.S. Forest Service, General Technical Report RM 120:49-53.

Brockerhoff, E.G., C.E. Ecroyd, A.C. Leckie, And M.O. KimberLey. 2003. Diversity and succession of adventive and indigenous vascular understorey plants in Pinus radiata plantation forests in New Zealand. Forest Ecology and Management 185:307-326.

Busch, D.E., AND S.D. SMITH. 1995. Mechanisms associated with the decline of woody species in riparian ecosystems of the southwestern U.S. Ecological Monographs 65:347-370.

Bush, J.K., AND O.W. VAN AukEN. 1986. Changes in nitrogen, carbon, and other surface soil properties during secondary succession. Soil Science Society of America Journal 50:1597-1601.
Chapin, F.S., L.R. Walker, C.L. Fastie, and L.C. SharMAN. 1994. Mechanisms of primary succession following deglaciation at Glacier Bay, Alaska. Ecological Monographs 64:149-175.

Cooper, D.J., D.C. Andersen, and R.A. Chimner. 2003. Multiple pathways for woody plant establishment on floodplains at local to regional scales. Journal of Ecology 91:182-196.

Dimitriou, L., AND P. Aronsson. 2004. Nitrogen leaching from short-rotation willow coppice after intensive irrigation with wastewater. Biomass and Bioenergy 26:433-441.

Di Tomaso, J.M. 1998. Impact, biology, and ecology of saltcedar (Tamarix spp.) in the southwestern United States. Weed Technology 12:326-336.

Dixon, M.D. 2003. Effects of flow pattern on riparian seedling recruitment on sandbars in the Wisconsin River, Wisconsin, USA. Wetlands 23:125-139.

ELLIS, L.M. 1995. Bird use of saltcedar and cottonwood vegetation in the middle Rio Grande valley of New Mexico, USA. Journal of Arid Environments 30: 339-349.

Ellis, L.M., C.S. Crawford, and M.C. Molles, Jr. 1997. Rodent communities in native and exotic riparian vegetation in the middle Rio Grande valley of central New Mexico. Southwestern Naturalist 42:13-19.

Engel-Wilson, R.W., And R.D. Ohmart. 1978. Floral and attendant faunal changes on the lower Rio Grande between Fort Quitman and Presidio, Texas. Pages 139-147 in R.R. Johnson and J.F. McCormick, technical coordinators, Strategies for protection and management of floodplain wetlands and other riparian ecosystems. Symposium proceedings. U.S. Department of Agriculture, Forest Service General Technical Report WO-12.

EveritT, B.L. 1980. Ecology of saltcedar-a plea for research. Environmental Geology 3:77-84.

Fastie, C.L. 1995. Causes and ecosystem consequences of multiple pathways of primary succession at Glacier Bay, Alaska. Ecology 76:1899-1916.

FONDA, R.W. 1974. Forest succession in relation to river terrace development in Olympic National Park, Washington. Ecology 55:927-942.

Friedman, J.M., W.R. Osterkamp, and W.M. Lewis. 1996. Channel narrowing and vegetation development following a Great Plains flood. Ecology 77:2167-2181.

GARY, H.L. 1965. Some site relations in three floodplain communities in central Arizona. Journal of the Arizona Academy of Science 3:209-212.

GRAF, W.L. 1982. Tamarisk and river-channel management. Environmental Management 6:283-296.

1988. Fluvial processes in dryland rivers. SpringerVerlag, New York.

Grossman, D.H., D. Faber-Langendoen, A.S. Weakly, M. Anderson, P. Bourgeron, R. Crawford, K. GOODIN, ET AL. 1998. International classification of ecological communities: terrestrial vegetation of the United States. Volume I. The national vegetation classification system: development, status, and applications. The Nature Conservancy, Arlington, VA.

HARRIS, R.R. 1987. Occurrence of vegetation on geomorphic surfaces in the active floodplain of a California alluvial stream. American Midland Naturalist 118: 393-405.

Hem, J.D. 1967. Composition of saline residues on leaves and stems of saltcedar (Tamarix pentandra Pallas). 
Geological Survey Professional Paper 491-C, U.S. Government Printing Office, Washington, DC.

Higgins, S.I., K.H. Rodgers, And J. Kemper. 1997. A description of the functional vegetation pattern of a semi-arid floodplain, South Africa. Plant Ecology 129:95-101.

Hildebrandt, T.D., and R.D. Ohmart. 1982. Biological resource inventory (vegetation and wildlife), Pecos River basin, New Mexico and Texas. Unpublished report to Bureau of Reclamation.

Holl, K.D., And E.E. Crone. 2004. Applicability of landscape and island biogeography theory to restoration of riparian understorey plants. Journal of Applied Ecology 41:922-933.

Horton, J.S. 1964. Notes on the introduction of deciduous tamarisk. Research Note RM-16, Rocky Mountain Forest and Range Experiment Station, Fort Collins, CO. 7 pp.

Horton, J.L., S.C. Hart, and T.E. Kolb. 2003. Physiological condition and water source use of Sonoran Desert riparian trees at the Bill Williams River, Arizona, USA. Isotopes in Environmental Health Studies 39:69-82.

Horton, J.L., T.E. Kolb, and S.C. Hart. 2001. Physiological response to groundwater depth varies among species and with river flow regulation. Ecological Applications 11:1046-1059.

Huckleberry, G. 1996. Historical channel changes on the San Pedro River, southeastern Arizona. Arizona Geological Survey, Tucson, AZ, USA. Open File Report 96-15.

Hughes, F.M.R. 1997. Floodplain biogeomorphology. Progress in Physical Geography 21:501-529.

Hultine, K.R., D.G. Williams, S.S.O. Burgess, and T.O. KeEFER. 2003. Contrasting patterns of hydraulic redistribution in three desert phreatophytes. Oecologia 135:167-175.

Hunter, W.C., R.D. OhmarT, and B.W. Anderson. 1988. Use of exotic saltcedar (Tamarix chinensis) by birds in arid riparian systems. Condor 90:113-123.

Hupp, C.R., AND W.R. OsterKamp. 1996. Riparian vegetation and fluvial geomorphic processes. Geomorphology 14:277-295.

Johnson, W.C., R.L. Burgess, and W.R. Keammerer. 1976. Forest overstory vegetation and environment on the Missouri River floodplain in North Dakota. Ecological Monographs 46:59-84.

Kearney, T.H., and R.H. Peebles. 1960. Arizona flora. University of California Press, Berkeley.

Kennedy, T.A., AND S.E. HobBIE. 2004. Saltcedar (Tamarix ramosissima) invasion alters organic matter dynamics in a desert stream. Freshwater Biology 49:65-76.

Landres, P.B, P. Morgan, and F.J. Swanson. 1999. Overview of the use of natural variability concepts in managing ecological systems. Ecological Applications 9: 1179-1188

Lite, S.J., AND J.C. Stromberg. 2005. Ground-water and surface water thresholds for maintaining PopulusSalix forests, San Pedro River, Arizona. Biological Conservation 125:153-167.

Lite, S.J., K.J. Bagstad, and J.C. Stromberg. 2005. Riparian plant species richness across lateral and longitudinal gradients of water stress and flood disturbance, San Pedro River, Arizona, USA. Journal of Arid Environments 63:785-813.
LYON, J., AND C.L. SAGERS. 1998. Structure of herbaceous plant assemblages in a forested riparian landscape. Plant Ecology 138:1-16.

Matic, S., J. Vuvelic, AND I. ANIC. 1999. Succession and sylvicultural treatments in riparian forests of the Croatian Podunavlje region. Ekologia-Bratislava 18: 39-46 (Supplement 1).

McQueEn, I.S., AND R.F. Miller. 1972. Soil-moisture and energy relationships associated with riparian vegetation near San Carlos, Arizona. Geological Survey Professional Paper 655-E:1-51.

Minckley, W.L., and T.O. Clark. 1984. Formation and destruction of a Gila River mesquite bosque community. Desert Plants 6:23-30.

Nakamura, F., T. Yajima, and S. Kikuchi. 1997. Structure and composition of riparian forests with special reference to geomorphic site conditions along the Tokachi River, northern Japan. Plant Ecology 133:209-219.

Pabst, R.J., And T.A. SPIEs. 1998. Distribution of herbs and shrubs in relation to landform and canopy cover in riparian forests of coastal Oregon. Canadian Journal of Botany 76:298-315.

PicketT, S.T.A., And P.S. White. 1985. The ecology of natural disturbance and patch dynamics. Academic Press, San Diego, CA.

Pope, G.L., P.D. Rigas, And C.F. Smith. 1998. Statistical summaries of streamflow data and characteristics of drainage basins for selected streamflow-gaging stations in Arizona through water year 1996. Water Resources Investigations Report 98-4225:1-907.

Robinson, T.W. 1965. Introduction, spread, and areal extent of salt cedar (Tamarix) in the western states. Geological Survey Professional Paper 491-A:1-13.

SAGERS, C.L., AND J. LyON. 1997. Gradient analysis in a riparian landscape: contrasts among forest layers. Forest Ecology and Management 96(1-2):13-26.

Sakai, T., H. Tanaka, M. Shibata, W. Suzuki, H. Nomiya, T. Kanazashi, S. IIDA, and T. NaKashizuKa. 1999. Riparian disturbance and community structure of a Quercus-Ulmus forest in central Japan. Plant Ecology 140:99-109.

Salinas, M.J., G. Blanca, and A.T. Romero. 2000. Riparian vegetation and water chemistry in a basin under semiarid Mediterranean climate, Andarax River, Spain. Environmental Management 26:539-552.

Schade, J.D., R. Sponseller, S.L. Collins, and A. Stiles 2003. The influence of Prosopis canopies on understory vegetation: effects of landscape position. Journal of Vegetation Science 14:743-750.

SCHNitZler, A. 1995. Successional status of trees in a gallery forest along the Rhine River. Journal of Vegetation Science 6:479-486.

Schwendenmann, L. 2000. Soil properties of boreal riparian plant communities in relation to natural succession and clear-cutting, Peace River lowlands, Wood Buffalo National Park, Canada. Water, Air and Soil Pollution 122:449-467.

ScotT, M.L., G.T. Auble, And J.M. Friedman. 1997. Flood dependency of cottonwood establishment along the Missouri River, Montana, USA. Ecological Applications 7:677-690.

SElmants, P.C., and D.H. KNight. 2003. Understory plant species composition 30-50 years after clearcutting in southeastern Wyoming coniferous forests. Forest Ecology and Management 185:275-289. 
Shafroth, P.B., G.T. Auble, J.C. Stromberg, and D.T. PATTEN. 1998. Establishment of woody riparian vegetation in relation to annual patterns of streamflow, Bill Williams River, Arizona. Wetlands 18:577-590.

Shafroth, P.B., J.M. Friedman, and L.S. Ischinger. 1995. Effects of salinity on establishment of Populus fremontii (cottonwood) and Tamarix ramosissima (saltcedar) in southwestern United States. Great Basin Naturalist 55:58-65.

Sher, A.A., D.L. Marshall, and S.A. Gilbert. 2000. Competition between native Populus deltoides and invasive Tamarix ramosissima and the implications for reestablishing flooding disturbance. Conservation Biology 14:1744-1754.

Sher, A.A., D.L. Marshall, AND J.P. TAYLOR. 2002. Establishment patterns of native Populus and Salix in the presence of invasive nonnative Tamarix. Ecological Applications 12:760-722.

SNydER, K.A., AND D.G. Williams. 2000. Water sources used by riparian trees varies among stream types on the San Pedro River. Journal of Agricultural and Forest Meteorology 105:227-240.

SPSS. 1998. SYSTAT, version 9. SPSS, Inc., Chicago, IL.

Stringham, T.K, W.C. Krueger, and D.R. Thomas. 2001. Application of non-equilibrium ecology to rangeland riparian zones. Journal of Range Management 54: 210-217.

StromberG, J.C. 1993. Riparian mesquite forests: a review of their ecology, threats, and recovery potential. Journal of the Arizona-Nevada Academy of Science 27:111-124.

1997. Growth and survivorship of Fremont cottonwood, Goodding willow, and salt cedar seedlings after large floods in central Arizona. Great Basin Naturalist 57:198-208.

1998a. Dynamics of Fremont cottonwood (Populus fremontii) and saltcedar (Tamarix chinensis) populations along the San Pedro River, Arizona. Journal of Arid Environments 40:133-155.

1998b. Functional equivalency of saltcedar (Tamarix chinensis) and Fremont cottonwood (Populus fremontii) along a free-flowing river. Wetlands 18:675676

Stromberg, J.C., J. Fry, and D.T. Patten. 1997. Marsh development after large floods in an alluvial, aridland river. Wetlands 17:292-300.

Stromberg, J.C., B.D. Richter, D.T. Patten, and L.G. WOLDEN. 1993. Response of a Sonoran riparian forest to a 10 -year return flood. Great Basin Naturalist 53 : $118-130$

USDA-NRCS. 2002. The PLANTS database, version 3.5. National Plant Data Center, Baton Rouge, LA. Available from: http://plants.usda.gov

van Coller, A.L., K.H. Rogers, and G.L. Heritage. 2000. Riparian vegetation-environment relationships: complimentarity of gradients versus patch hierarchy approaches. Journal of Vegetation Science 11:337-350.

Vandersande, M.W., E.P. GLENN, AND J.L. WALWORTh. 2001. Tolerance of five riparian plants from the lower Colorado River to salinity drought and inundation. Journal of Arid Environments 49:147-159.

Van Hylckama, T.E.A. 1980. Weather and evapotranspiration studies in a saltcedar thicket, Arizona. Geological Survey Professional Paper 491-F, U.S. Government Printing Office, Washington, DC.

Virginia, R.A., AND W.M. JARRELL. 1983. Soil properties in a mesquite-dominated Sonoran Desert, California, USA ecosystem. Soil Science Society of America Journal 47:138-144.

WALKER, L.R. 1989. Soil nitrogen changes during primary succession on a floodplain in Alaska, USA. Arctic and Alpine Research 21:341-349.

Walker, L.R., And S. Smith. 1997. Impacts of invasive plants on community and ecosystem properties. Pages 69-86 in J.O. Luken and J.W. Thieret, editors, Assessment and management of plant invasions. Springer-Verlag, New York.

WEST Consultants, InC. 1998. WinXSPRO: a channel cross section analyzer. User's manual. USDA Forest Service, Rocky Mountain Experiment Station. Fort Collins, CO. 97 pp.

Wilson, R.E. 1970. Succession in stands of Populus deltoides along the Missouri River in southeastern South Dakota. American Midland Naturalist 83:330-342.

Xiong, S.J., C. Nilsson, M.E. Johansson, and R. Jansson. 2001. Responses of riparian plants to accumulation of silt and plant litter: the importance of plant traits. Journal of Vegetation Science 12:481-490.

Zimmerman, J.C., L.E. DeWald, and P.G. Rowlands. 1999. Vegetation diversity in an interconnected ephemeral riparian system of north-central Arizona, USA. Biological Conservation 90:217-228.

Received 22 June 2004 Accepted 2 March 2005 